\title{
Median Nerve Behavior in Different Upper Limb Positions
}

\author{
Comportamiento del Nervio Mediano en Diferentes Posiciones del Miembro Superior
}

\author{
"Mariane Pettian; "Amilton Iatecola; "Cesar Adriano Dias Vecina; ** Maria José Salete Viotto; \\ ${ }^{*, * * *}$ Ricardo Noboro Isayama; ${ }^{* * * *}$ Evanisi Teresa Palomari $\&{ }^{*, * * * * *}$ Marcelo Rodrigues da Cunha
}

\begin{abstract}
PETTIAN, M.; IATECOLA, A.; VECINA, C. A. D.; VIOTTO, M. J. S.; ISAYAMA, R. N.; PALOMARI, E. T. \& DA CUNHA, M. R. Median nerve behavior in different upper limb positions. Int. J. Morphol., 30(4):1280-1284, 2012.

SUMMARY: The neural compression syndromes peripheral upper limb are common in clinical medicine and the causes range from trauma and occupational factors. Technical evaluation manuals as neural tension at different positions of the upper limb as well as knowledge of the topography of the affected nerve are essential for accurate diagnosis. The objective of this study was to analyze the behavior of the median nerve in different positions of the upper limb. Fifteen formalin-fixed cadavers were used for morphometric and topographic evaluation of the median nerve in different positions of the right upper limb. In all cases analyzed, the median nerve originated from the lateral and medial fascicles of the brachial plexus and attended by the arm and forearm in accordance with the classical descriptions in the literature. Measurement of the length of the nerve in different positions of the upper limb showed greater stretching during the position that combined extension and external rotation of the shoulder and extension of the elbow/wrist/fingers. In conclusion, the metric landmarks and positions studied are important for the precise diagnosis of median nerve neurobiomechanics in nerve compression syndromes.
\end{abstract}

KEY WORDS: Median nerve; Positions; Anatomy.

\section{INTRODUCTION}

Peripheral nerve injuries of the upper limb are common and can cause severe sensory and motor deficits that have socioeconomic repercussions and the median nerve of the brachial plexus is the peripheral nerve most frequently affected because of its anatomic location that renders it vulnerable to traumas and occupational diseases (Ferreira, 2001). Carpal tunnel syndrome involving the median nerve is the most common nerve compression syndrome which, in most cases, is the result of nonspecific chronic flexor tenosynovitis (Jablecki et al., 1993; Kouyoumdjian, 1999). Other disorders such as radiculopathy, plexopathy, polyneuropathy, osteoarticular injuries and compression of the median nerve itself at other sites have been cited in the literature as possible etiologies (Brain et al., 1947; Stevens, 1997).

The diseases described above cause restriction of median nerve mobility in relation to connective tissues along its course through the neural canal and at its interfaces with soft tissues and adjacent bones (McLelland \& Swash, 1976). The physiopathologic alterations such as the formation of fibrosis in connective tissue surrounding the nerve might be responsible for changes in blood flow and the consequent development of nerve fiber ischemia Mackinnon (2002). In addition, these alterations may reduce the capacity of the nerve to slide along the interface during upper limb movements, thus increasing neural tension. This restricted sliding of peripheral nerves has been suggested to be one of the factors that contribute to the physiopathology of nerve compression syndromes (McLelland \& Swash). Mahmud (2006) suggested that the neural tension of median nerve have a participation in the physiopathology of the carpal tunnel syndrome and the use of therapeutical procedures that diminish the development of neural tension. In this respect, neural tension tests have been used to evaluate the presence of biomechanical restriction of the median nerve by performing various types of upper limb stretching that exert stress on the nerve (Mackinnon; Ekstrom \& Holden, 2002).

The objective of the present study was to evaluate the morphology condition of the median nerve in different positions of the upper limb.

* Laboratory of Anatomy, Faculty Nossa Senhora do Patrocínio, Itu-SP, Brazil.

** Laboratory of Anatomy, Department of Morphology and Pathology, Federal University of São Carlos, São Carlos - SP, Brazil.

*** Adventist University Center of São Paulo, Campus I, São Paulo-SP, Brazil.

****** Department of Anatomy, State University of Campinas, Campinas-SP, Brazil.

******* Department of Morphology and Pathology, Faculty of Medicine of Jundiaí, São Paulo, Brazil. Rua Francisco Telles, 250, Vila Arens, Jundiaí - SP, Brazil. 


\section{MATERIAL AND METHOD}

Samples. Fifteen formalin-fixed male cadavers obtained from Laboratory of Anatomy, Faculty Nossa Senhora do Patrocínio and from the Department of Morphology and Pathology, Faculty of Medicine of Jundiaí, Brazil, were used. The upper limbs were placed in the following positions using a goniometer: A) anatomic; B) shoulder abduction $\left(90^{\circ}\right)$ / elbow flexion $\left(90^{\circ}\right)$ / neutral wrist position; C) shoulder abduction $\left(90^{\circ}\right) /$ elbow extension $\left(0^{\circ}\right) /$ wrist extension $\left(85^{\circ}\right)$; D) extension $\left(45^{\circ}\right)$ and external rotation $\left(90^{\circ}\right)$ of the shoulder / elbow extension $\left(0^{\circ}\right) /$ extension of the wrist $\left(85^{\circ}\right)$ and fingers $\left(20^{\circ}\right)$.

To analyze the length of the median nerve in the four positions we used as a reference proximal to its formation by the union of medial and lateral roots of the brachial plexus as the distal reference was passing through the proximal
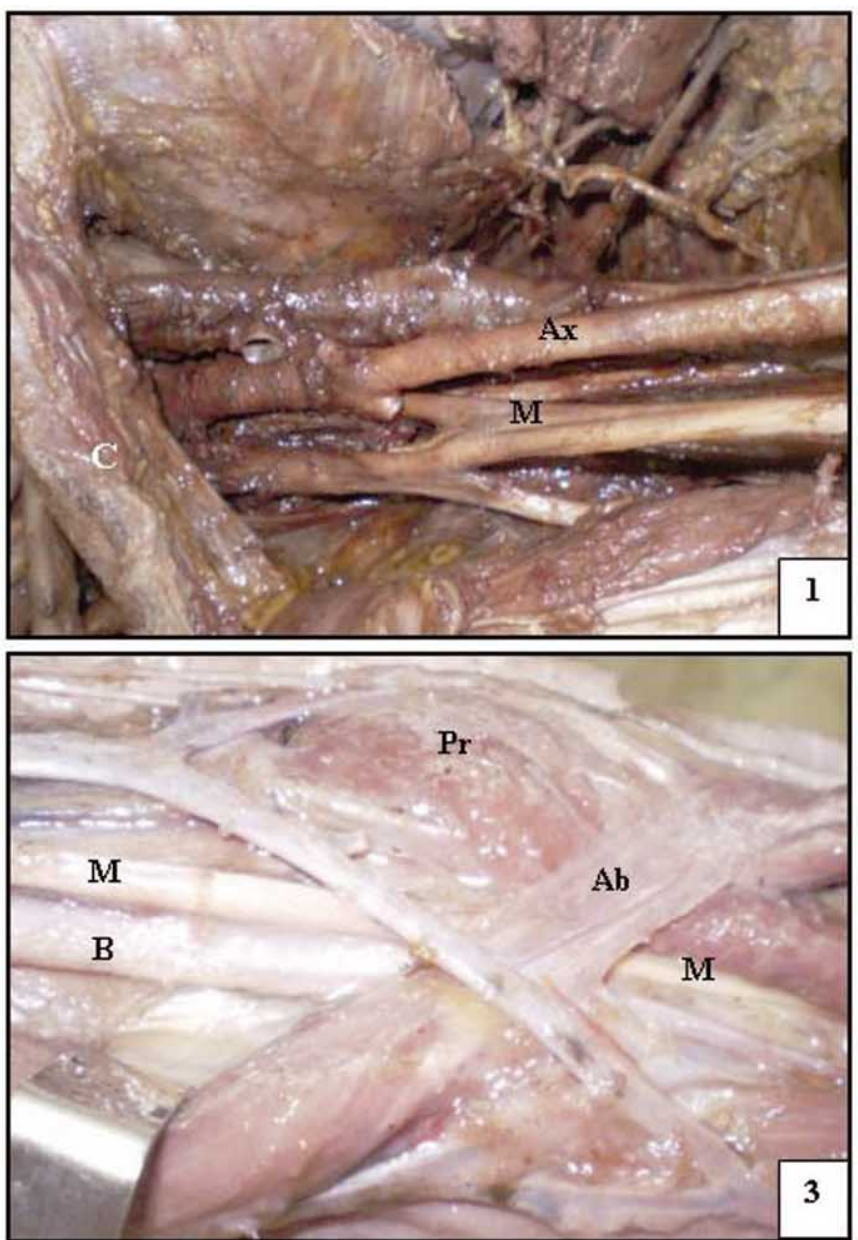

Figs. 1-4. Anatomic position of median nerve in the axillary fossa, medial bicipital sulcus, cubital fossa and wrist, respectively. In the axillary fossa, note the median nerve $(\mathrm{M})$ originated in the infraclavicular region from the brachial plexus and its relationship with the axillary artery (Ax). In the medial bicipital sulcus, note the formation of this sulcus between biceps (Bi) and triceps (T) brachii muscles, which lodges the median nerve (M), ulnar nerve (U), medial cutaneous nerve of the arm and forearm (Nc), basilic vein (Ba), and brachial artery (B). In the cubital fossa, observe the median nerve (M) parallel to the brachial artery (B), passing deep to the bicipital aponeurosis (Ab), continuing in the forearm, passing through the heads of the pronator teres muscle (Pr). In the region of the wrist, note the superficial passage of the median nerve (M) between the insertion tendons of the flexor carpi radialis (F) and long palmar muscles (P). Indicated: Clavicle (c). margin of the flexor retinaculum. In addition, we analyzed in the anatomical position, the distance between the median nerve and middle third of the clavicle, coracoid process of the scapula, medial epicondyle of the humerus, and styloid process of the radius. The results obtained for the different positions adopted were compared by the ANOVA, with the level of significance set at $\mathrm{p}<0.05$.

\section{RESULTS}

Anatomic study. In all cases analyzed, the median nerve originated from the lateral and medial fascicles of the brachial plexus and attended by the arm and forearm in accordance with the classical descriptions in the literature (Figs. 1-4). However, anatomical changes were observed as the proximity of the origin of the median nerve in the middle third of the clavicle.
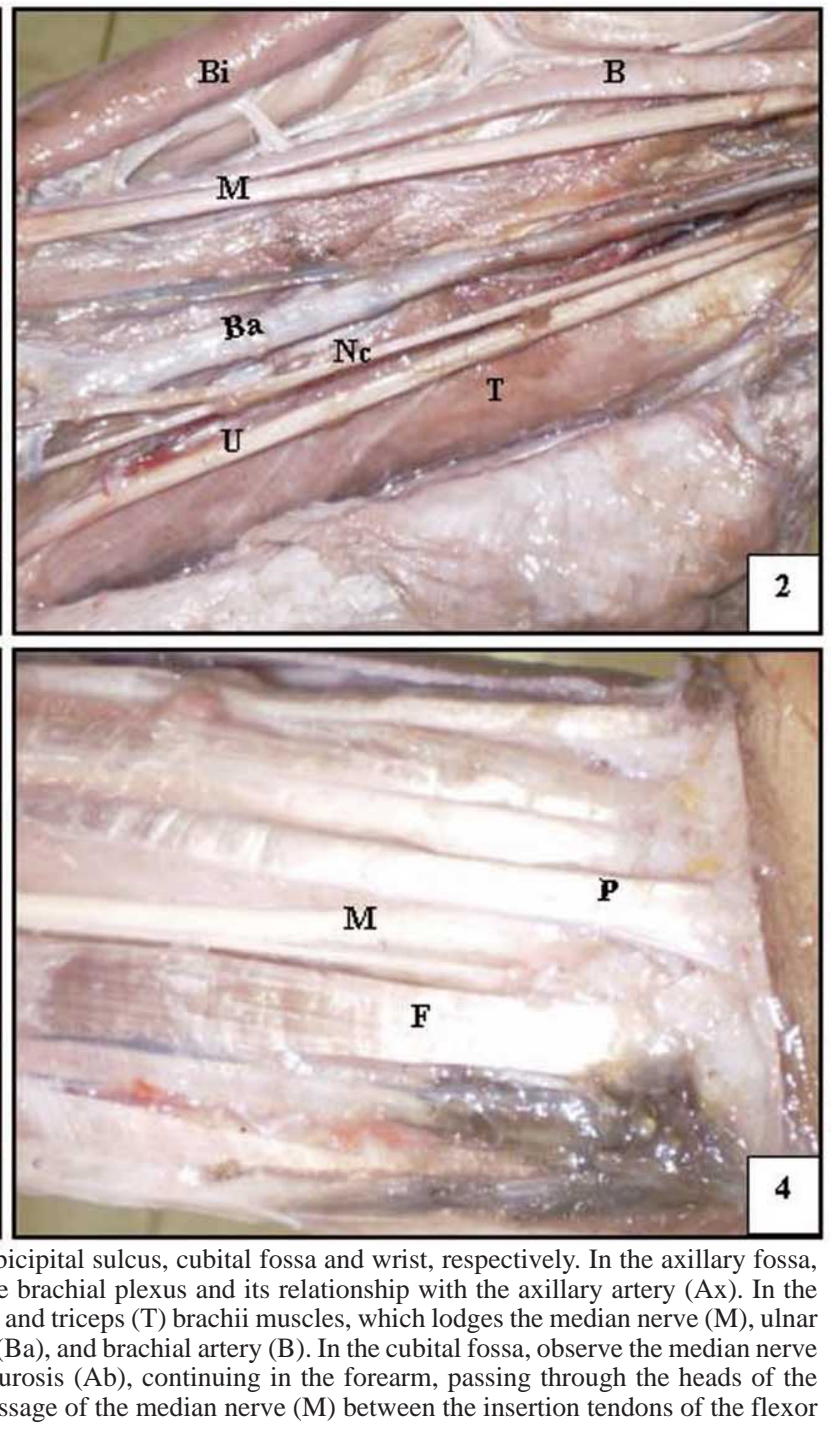
PETTIAN, M.; IATECOLA, A.; VECINA, C. A. D.; ViOTTO, M. J. S.; ISAYAMA, R. N.; PALOMARI, E. T. \& DA CUNHA, M. R. Median nerve behavior in different upper limb positions. Int. J. Morphol., 30(4):1280-1284, 2012.

In position $\mathrm{A}$, had not alteration in the behavior of the median nerve as regards its position anatomic and tension (Fig. 5). In the position B, the median nerve presented stretched visually in the axilla and relaxed at the elbow and wrist (Fig. 6). In position C (Fig. 7), the median nerve remained stretched visually in all upper limb being more considerable in the position D (Fig. 8).

Morphometric study. Evaluation of the length of the median nerve from its origin in the brachial plexus to its
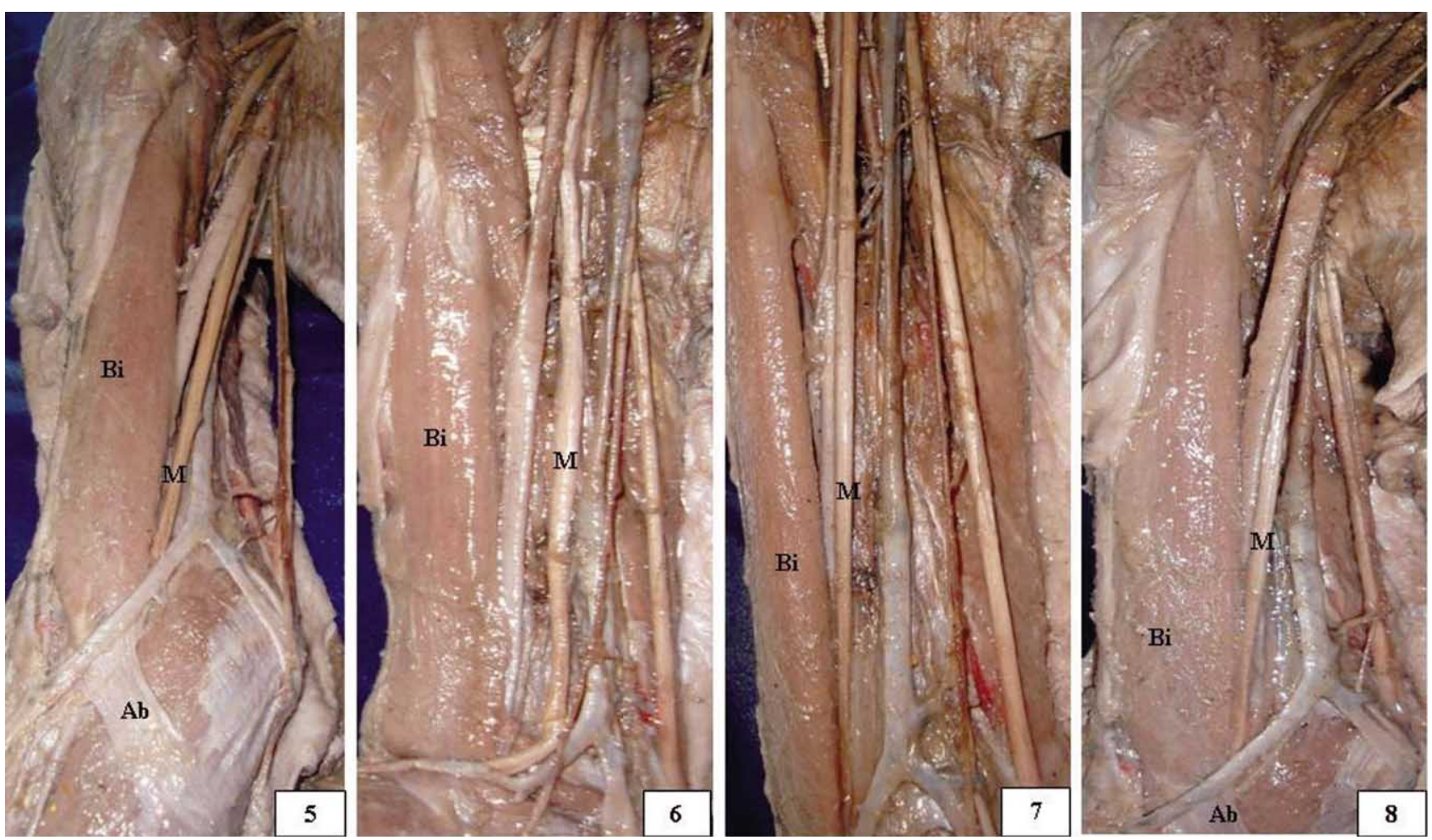

Figs. 5-8. Behavior of the median nerve in the arm in the positions A, B, C and D, respectively. In A, note the normal position of the median nerve(M). In $\mathrm{B}$, note the tension of median nerve in the axillary and relaxation in the cubital fossa. In C, Note the tension of median nerve in arm. In D, Note the considerable tension of median nerve in upper limb. Indicated: Bi (biceps muscle), Ab (bicipital aponeurosis).

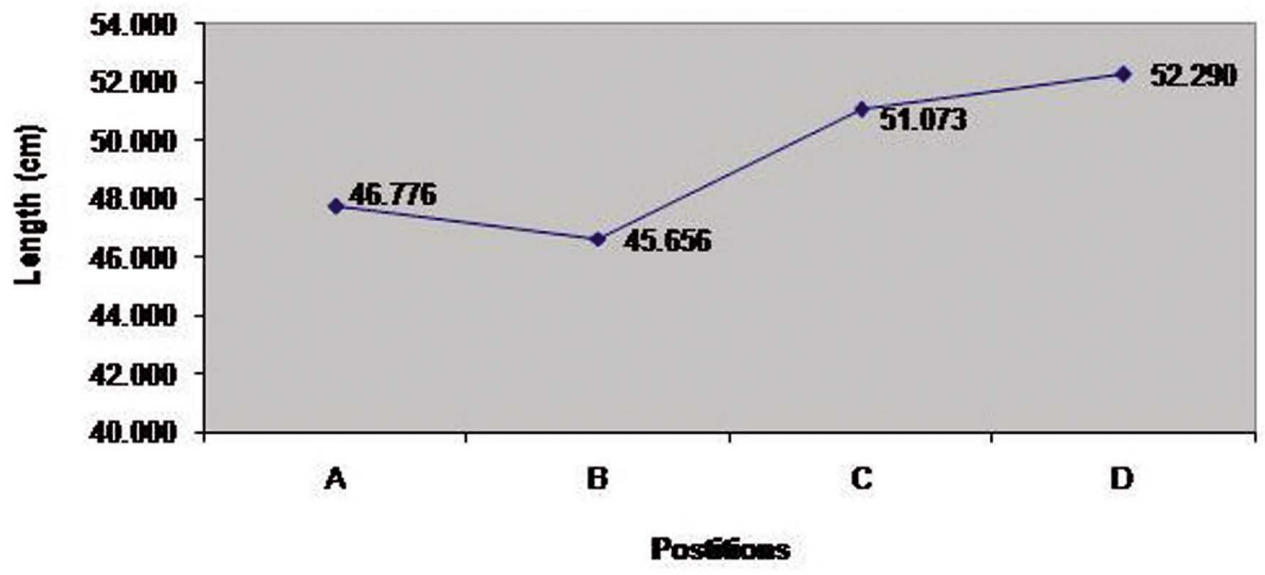

Fig. 9. Evaluation of the length of the median nerve in the four positions adopted (A, B, C, D). The median nerve showed more stretched visually in the positions adopted $\mathrm{C}$ and $\mathrm{D}$. 


\section{DISCUSSION}

Neural tests were first developed by Elvey (1979) and are based on different positions of the upper limb that lead to maximum stretching of the peripheral nerves, generating neural tension that reproduces the clinical symptoms of nerve compression. Kenneally et al. (1988), examining the location of nerves in relation to joint range of motion, developed techniques to selectively stress individual nerves. These techniques were subsequently refined by Butler (2003) who studied the brachial plexus and elaborated tension maneuvers for each nerve.

Chavany (1934) suggested a test for the median nerve applying traction along the extended arm associated with abduction of the shoulder. In contrast, Frykholm (1951) proposed the addition of lateral flexion of the head contralateral to the side of the nerve of the brachial plexus studied. McLellan \& Swash inserted needle electrodes into the median nerves of 15 volunteers and measured their position during various movements of the arm and neck. The authors observed displacement of the median nerve of less than $7.4 \mathrm{~mm}$ in the case of wrist and finger extension associated with contralateral flexion of the neck and concluded that these joint movements exert stress on the median nerve along its anatomic course.

According to Butler, the position that puts most stress on the median nerve is depression of the shoulder girdle, shoulder abduction associated with external rotation, and elbow and wrist extension. In a cadaver study, Wright et al. (1996), measured the tension and course of the median nerve in different positions of the upper limb. The results showed an increase in median nerve tension mainly when movements of shoulder abduction were combined with extension of the elbow and wrist. Similar findings were obtained in the present study as demonstrated by an increase of median nerve length when the same position was adopted. However, the position consisting of extension and external rotation of the shoulder associated with extension of the elbow, wrist and fingers also promoted marked tension in the median nerve.

Morphologic analysis of the median nerve showed no anatomic variations during its passage through the neural canal of the right upper limb. However, differences were noted in the level of its formation in the infraclavicular region by junction of the branches of the medial and lateral fasciculi of the brachial plexus. In this case, the origin of the median nerve in the axillary region was either closer to or more distant from the midpoint of the clavicle. The distances of the median nerve relative to the bony projections studied here are important metric landmarks for a more precise identification of the topography of this nerve. In the study of Satyanarayana et al. (2009), anomalous median nerves with regard to their formation were found in three different adult male cadavers. In one cadaver, there was variation in the formation of the median nerve and its relation with the axillary artery. Another cadaver revealed the formation of the median nerve by three roots, while in the third one, the median nerve was found to be formed by four roots. Saeed \& Rufai (2003) observed that the median nerve was formed by the fusion of three roots, two from the lateral and one from the medial cord of the brachial plexus. The variant lateral root of the median nerve followed an anomalous course, crossing anterior to the distal part of the axillary artery. Those variations are important particularly to the surgeons for carrying out surgical procedures in axilla and arm.

We conclude that different positions of the upper limb provoke alterations in the tension of the median nerve. In view of the importance of the topography and neurodynamics of the median nerve, the present results contribute to the localization and to a more precise evaluation of themorphofunctional conditions of this nerve in different positions of the upper limb and might be used for the assessment and treatment of nerve compression syndromes involving the median nerve.

PETTIAN, M.; IATECOLA, A.; Vecina, C. A. D.; VIOTTO, M. J. S.; ISAYAMA, R. N.; PALOMARI, E. T. \& DA CUNHA, M. R. Comportamiento del nervio mediano en diferentes posiciones del miembro superior. Int. J. Morphol., 30(4):1280-1284, 2012.

RESUMEN: Los síndromes de compresión de los nervios periféricos del miembro superior son comunes en la medicina clínica, y sus causas comprenden traumas y factores ocupacionales. Manuales de evaluación técnica y la tensión neural en diferentes posiciones del miembro superior, así como el conocimiento de la topografía del nervio afectado, son esenciales para un diagnóstico preciso. El objetivo de este estudio fue analizar el comportamiento del nervio mediano en diferentes posiciones del miembro superior. Fueron utilizados 15 cadáveres fijados en formol. Se realizó la evaluación morfométrica y topográfica del nervio mediano en diferentes posiciones del miembro superior derecho. En todos los casos analizados, el nervio mediano se originó desde los fascículos lateral y medial del plexo braquial, y recorrieron el brazo y el antebrazo de acuerdo con las descripciones clásicas. La medición de la longitud del nervio en las diferentes posiciones mostró un mayor estiramiento durante la posición combinada de extensión y rotación lateral del hombro y extensión del codo/muñeca/dedos. En conclusión, los puntos de referencia y posiciones métricas estudiadas son importantes para un diagnóstico sdrcusdo de la neurobiomecánica del nervio mediano en los síndromes de compresión nerviosa.

PALABRAS CLAVE: Nervio mediano; Posiciones; Anatomía. 


\section{REFERENCES}

Butler, D. Mobilization of the nervous system. $2^{\text {a }}$ ed. São Paulo, Manole, 2003.

Brain, W. R.; Wright, A. D. \& Wilkinson, M. Spontaneous compression of both median nerves in the carpal tunnel: six cases treated surgically. Lancet, 1(6443-6445):277-82, 1947.

Chavany, J. A. A propos des neuralgies cervico-brachiales. Bulletin Medical (Paris), 48:335-9, 1934.

Ekstrom, R. A. \& Holden, K. Examination of and intervention for a patient with chronic lateral elbow pain with signs of nerve entrapment. Phys. Ther., 82(11):1077-86, 2002.

Elvey RL. Brachial plexus tension test and the patholoanatomical origin of arm pain. In: Idczak, R. (Ed.). Aspects of Manipulative Therapy. Melbourne, Lincoln Institute of Health Sciences, 1979

Ferreira, A. S. Peripheral nervous lesions: diagnosis and handling. $2^{\mathrm{a}}$ ed. São Paulo, Santos, 2001.

Frykholm, R. The mechanism of cervical radicular lesions resulting from friction or forceful traction. Acta Chir. Scand., 102(2):938, 1951.

Jablecki, C. K.; Andary, M. T.; So, Y. T.; Wilkins, D. E. \& Willians, F. H. Literature review of the usefulness of nerve conduction studies and electromyography for the evaluation of patients with carpal tunnel syndrome. Muscle Nerve, 16(12):1392-414, 1993.

Kenneally, M.; Rubenach, H. \& Elvey, R. The upper limb tension test: The SLR of the arm. In: Grant, R. (Ed.). Physical Therapy of the Cervical and Thoracic Spine. New York, Churchill Livingstone, 1988.

Kouyoumdjian, J. A. Síndrome do túnel do carpo: aspectos clínicoepidemiológicos em 668 casos. Arq. Neuropsiquiatr., 57(2A):202-7, 1999.

Mackinnon, S. E. Pathophysiology of nerve compression. Hand Clin., 18(2):231-41, 2002.

Mahmud, M. A.; Merlo, A. R.; Gomes, I.; Becker, J. \& Nora, D. B. Relationship between adverse neural tension and nerve conduction studies in patients with symptoms of the carpal tunnel syndrome. Arq. Neuropsiquiatr., 64(2A):277-82, 2006.

McLelland, D. L. \& Swash, M. Longitudinal sliding of the median nerve during movements of the upper limb. J. Neurol. Neurosurg. Psychiatry, 39(6):566-70, 1976.

Saeed, M. \& Rufai, A. A. Median and musculocutaneous nerves: variant formation and distribuition. Clin. Anat., 16(5):453-7, 2003.
Satyanarayana, N.; Vishwakarma, N.; Kumar, G. P.; Guha, R.; Dattal, A. K. \& Sunitha, P. Rare variations in the formation of median nerve-embryological basis and clinical significance. Nepal Med. Coll. J., 11(4):287-90, 2009.

Stevens, J. C. AAEM minimonograph \#26: the electrodiagnosis of carpal tunnel syndrome. American Association of Electrodiagnostic Medicine. Muscle Nerve, 20(12):1477-86, 1997.

Wright, T. W.; Glowczewskie, F.; Wheeler, D.; Miller, G. \& Cowin, D. Execursion and strain of the median nerve. J. Bone Joint Surg. Am., 78(12):1897-903, 1996.

Correspondence to:

Prof. Dr. Marcelo Rodrigues da Cunha

Department of Morphology and Pathology

Faculty of Medicine of Jundiaí

Rua Francisco Telles, 250, Vila Arens, Jundiaí - SP

CEP. 13202-550, Cx. Postal 1295

BRAZIL

Phone/Fax: 55-1145871095

Email: cunhamr@hotmail.com

Received: 29-03-2012

Accepted: 31-07-2012 